\title{
SPOTLIGHT ON HEALTH GRANTMAKING IN GEORGIA
}

The Foundation Center's mission is to strengthen the nonprofit sector by advancing knowledge about U.S. philanthropy. We hope that this brief exploration of top health funders and their giving patterns will provide insights into the state of health grantmaking in Georgia.

This report includes statistical charts and tables based on the Center's annual grants sample, a mini-directory of Georgia-based health funders, and a statistical snapshot of Georgia's health rankings produced by the Healthcare Georgia Foundation.

\section{GEORGIA GRANTS SAMPLE}

Each year the Foundation Center indexes all of the grants of $\$ 10,000$ and more awarded by close to 1,200 of the nation's largest private and community foundations. Our most recent (2005) sample includes nearly 131,000 grants awarded by 1,154 U.S. foundations totaling $\$ 16.4$ billion. Of the 1,172 foundations in the sample, this report analyzes health grants made to Georgia recipients by 108 foundations, 19 that are based in Georgia and 89 that are based outside Georgia, totaling \$88 million.

\section{PRIMARY PURPOSE}

Funding for general and rehabilitative health-which includes support for hospitals and in-patient care, outpatient clinics and care, public health, reproductive health, and health care financing and policy, among other purposes-accounted for nearly $72 \%$ of all Georgia giving for health in 2005 . Within that category, more than half targeted public health. Georgia-based foundations were far more likely to support care and treatment of mental health than were non-Georgia foundations; in terms of support for medical research, the opposite was true.

\section{TARGET POPULATION}

Among specified population groups, children and youth and people with disabilities benefitted from the most Georgiafocused grant dollars, $18.2 \%$ and $17.5 \%$ respectively. Women and girls were at the other end of the spectrum, specifically benefiting from 3.2\% of total grant dollars for health in Georgia. Economically disadvantaged and minority populations were in the middle, each benefiting from just over $8 \%$ of total grant dollars.
Health funders preferred giving to general \& rehabilitative health in Georgia in 2005

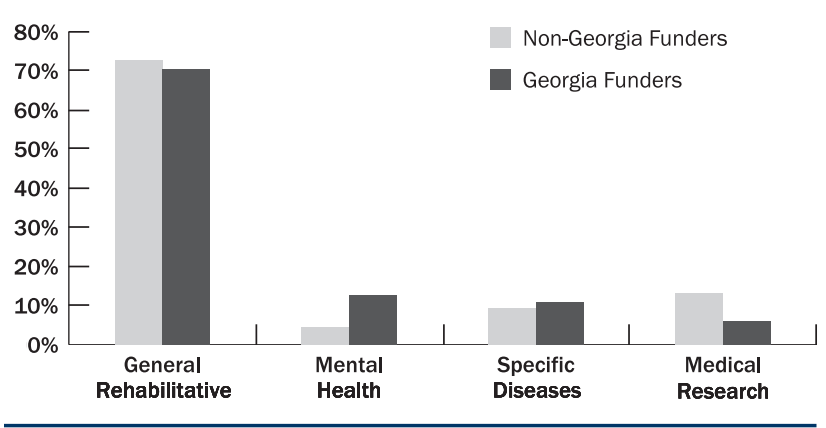

Source: The Foundation Center

Georgia's children \& youth received the largest share of foundation health grant dollars in 2005

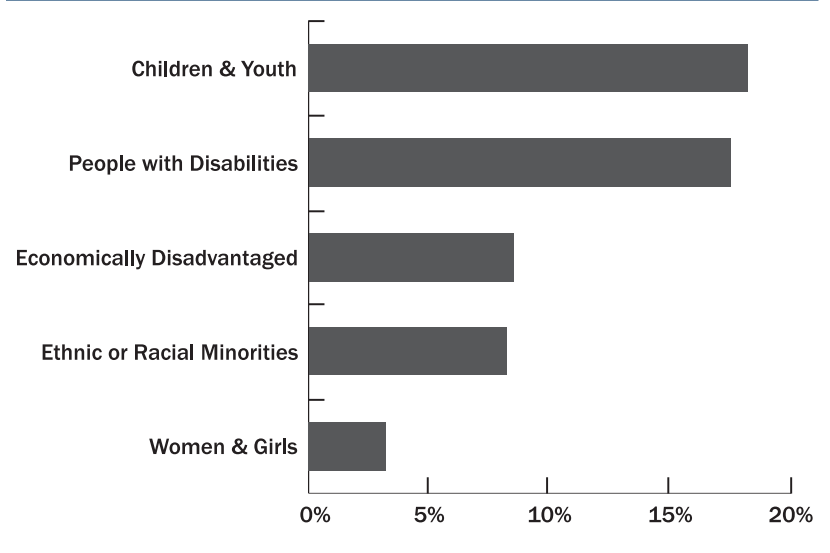

Source: The Foundation Center

A target population could be identified for $44 \%$ of all grant dollars. Chart includes selected beneficiary groups representing at least 3 percent of all grant dollars. Figures represent only grants awarded to groups that could be identified as serving specific populations or grants whose descriptions specified a benefit for a specific population. These figures do not represent all giving benefiting these groups. In addition, grants may benefit multiple population groups, e.g., a grant for minority women, and would therefore be counted more than once.

"Spotlight on Health Grantmaking in Georgia" is sponsored by:

Healthcare Georgia Foundation

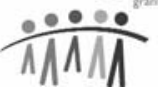




\section{A MINI-DIRECTORY OF GEORGIA FOUNDATIONS FUNDING HEALTH PROGRAMS}

The following private and community foundations were identified in the Foundation Center's 2005 grants sample as awarding the greatest number of health grant dollars to Georgia recipients. For most of the funders in this directory, health is just one among many areas of interest for their grantmaking. The descriptions provided here attempt to capture just their health interests but should not be taken as an indication that they devote their grantmaking exclusively to health.

\section{The Aflac Foundation, Inc. ${ }^{\wedge}$}

\section{Columbus}

Web: www.aflac.com

Description: The foundation supports

community health systems and organizations involved with education, pediatric cancer, disease, cancer research, public safety, and human services.

Selected Grants:

$\$ 1,005,000$ to American Red Cross, West Central Georgia Chapter, for National Disaster Relief Fund

$\$ 458,528$ to United Way of the Chattahoochee Valley for annual campaign $\$ 25,000$ to Saint Francis Hospital Foundation for capital campaign

The Peyton Anderson Foundation, Inc. $* \wedge$ Macon

Web: www.peytonanderson.org

Description: Giving primarily in Bibb County and Macon, GA, for the arts, education, housing development, and human services. Selected Grants:

$\$ 505,000$ to Medcen Foundation for Sylvia Bond Leadership Institute and construction of heart hospital

$\$ 12,500$ to Georgia Transplant Foundation for financial assistance for patients and to create Macon Satellite office

$\$ 1,300$ to Golden Rule for care and treatment of women substance abusers

The Arthur M. Blank Family Foundation*

Atlanta

Web: www.blankfoundation.org

Description: Promotes positive change in people's lives and builds and enhances the communities in which they live. Supports innovative endeavors leading to better circumstances for low-income youth and their families.

Selected Grants:

$\$ 1,000,000$ to Shepherd Center for capital support and endowment for therapeutic recreation programs

$\$ 20,000$ for Georgia Conservancy for Mothers and Others Clean Air Initiative

$\$ 14,550$ to Girls Inc. of Columbus and Phenix-Russel for Way To Go Kids fitness and nutritional program

\section{Bradley-Turner Foundation*^ \\ Columbus}

Description: Giving primarily for higher education, religious associations, community funds, and youth and social service agencies; support also for cultural and health-related programs.

Selected Grants:

$\$ 401,983$ to Columbus Regional Medical

Foundation for capital and operating support

$\$ 66,667$ to New Horizons Area MH-MR-SA Program for capital and operating support $\$ 40,000$ to Shepherd Center for capital, continuing and operating support

Callaway Foundation, Inc. $* \wedge$

LaGrange

Web: www.callawayfoundation.org

Description: Giving for health and hospitals;

community funds; care for the aged; and

community development.

Selected Grants:

$\$ 2,000,000$ to West Georgia Health

Foundation for new emergency care facility

$\$ 75,000$ to Twin Cedars Youth Services for building/renovation

$\$ 5,000$ to Camp Sunshine for summer camp for children with cancer

\section{J. Bulow Campbell Foundation*^ \\ Atlanta \\ Web: www.jbcf.org}

Description: Supports a variety of charitable organizations serving the general welfare of the community, education, youth, Christian concerns and, to a limited extent, arts and cultural organizations.

Selected Grants:

$\$ 1,000,000$ to George West Mental Health Foundation for building/renovation

$\$ 500,000$ to Metro Atlanta Recovery Residences for building/renovation

$\$ 250,000$ to CHRIS Kids for capital campaign for new group homes

\section{The Community Foundation for Greater Atlanta* $*$}

Atlanta

Web: www.atlcf.org

Description: Organized for the permanent administration of funds placed in trust by various donors for charitable purposes. Grants, unless designated by the donor, are confined to a 23-county metropolitan area of Atlanta, with emphasis on human services, arts and culture, education, health, and community development. Health priorities include services for the homeless, fitness and nutrition of school-aged children, and HIV/AIDS.

Selected Grants:

$\$ 148,497$ to Shepherd Center for continuing support

$\$ 17,000$ to Covenant Community for general/operating support

$\$ 10,000$ to Metropolitan Counseling Services

\section{The Wilbur and Hilda Glenn Family Foundation*}

Atlanta

Description: Supports education, health and

human services.

Selected Grants:

$\$ 650,000$ to Winship Cancer Institute at Emory University for cancer research and facility support

$\$ 300,000$ to Children's Healthcare of Atlanta for capital campaign

$\$ 100,000$ to Whitefoord Community Program to expand services and fund continuing operations

\section{Healthcare Georgia Foundation*^}

Atlanta

Web: www.healthcaregeorgia.org

Description: Health priorities include addressing health disparities, strengthening nonprofit health organizations, and expanding access to primary healthcare.

Selected Grants:

\$235,000 to National Council of La Raza Atlanta for the Georgia Latino/Hispanic Health Agenda and Leadership Project

$\$ 91,000$ to Three Rivers Area Health Education Center to participate in a beta test of a statewide distance learning network program serving nonprofit health organizations in west central Georgia

$\$ 10,000$ to Concerned Black Clergy of Metropolitan Atlanta to produce publication that addresses eating behaviors, physical activity, and childhood obesity within faith communities 
The Marcus Foundation, Inc.*

\section{Atlanta}

Description: Support primarily for human services, mental health, Jewish federated giving programs, education, and public affairs. Selected Grants:

$\$ 1,678,308$ to Shepherd Center for Marcus Community Bridge

$\$ 298,495$ to Link Counseling Center for general operations

$\$ 10,000$ to Health Students Taking Action Together for online journal

\section{The Carlos and Marguerite Mason Fund $* \wedge$}

Atlanta

Web: www.wachovia.com/privatefoundations Description: Support only for Georgia organizations involved with organ transplantation and related research. Selected Grants:

$\$ 550,000$ to Emory University Integrated Approach for Transplant Tolerance Partnership

$\$ 120,000$ to Children's Healthcare of Atlanta for pediatric nephrology program

$\$ 45,000$ to Georgia Transplant Foundation for apprenticeship program

\section{The M. L. Simpson Foundation Trust*}

Jackson

Description: Giving primarily for Baptist ministries, including a church and a seminary; funding also for medical research and an eye center.

Selected Grants:

$\$ 2,000,000$ to Emory University for Emory

Eye Center.

\section{The Tull Charitable Foundation $* \wedge$}

\section{Atlanta}

Web: www.tullfoundation.org

Description: To assist Georgia nonprofit organizations with one-time capital costs associated with the implementation of strategic growth initiatives.

Selected Grants:

$\$ 200,000$ to Metro Atlanta Recovery Residences for campaign to acquire land and for construction of additional residential facilities

$\$ 150,000$ to George West Mental Health Foundation for facility expansion and endowment

$\$ 100,000$ to American Red Cross, Metropolitan Atlanta Chapter for construction of new blood services facility in Douglasville

\section{Turner Foundation*}

\section{Atlanta}

Web: www.turnerfoundation.org

Description: Support in the areas of the environment and population focuses on safeguarding habitat, growing the movement, creating solutions for sustainable living, and healthy planet \& healthy communities.

Selected Grants:

$\$ 40,000$ to Planned Parenthood of Georgia $\$ 15,000$ to Feminist Women's Health Center $\$ 10,000$ to Juvenile Diabetes Research Foundation

\section{The UPS Foundation $\star \wedge$}

\section{Atlanta}

Web: www.community.ups.com

Description: The foundation supports organizations involved with education, obesity, hunger, nutrition, human services, community development, volunteerism, youth, senior citizens, disabled people, mentally disabled people, economically disadvantaged people, and homeless people. Special emphasis is directed toward programs designed to address hunger, literacy, and volunteerism.

\section{Selected Grants:}

$\$ 150,000$ to Link Counseling Center $\$ 80,000$ to Morehouse School of Medicine for continuing support

$\$ 15,000$ to Starlight Children's Foundation of Atlanta for general support

\section{Robert W. Woodruff Foundation*^}

Atlanta

Web: www.woodruff.org

Description: Principal giving interests are focused on the following program areas: elementary, secondary, and higher education; health care and education; human services, particularly for children and youth; economic development and civic affairs; art and cultural activities; and conservation of natural resources and environmental protection. Preference is given to one-time capital projects of established private charitable organizations.

Selected Grants:

$\$ 2,000,000$ to Atlanta Ronald McDonald House Charities for capital improvements $\$ 400,000$ to Link Counseling Center for capital improvements

$\$ 50,000$ to Georgia Transplant Foundation for implementation of Transplant Saving Account program

\begin{tabular}{|c|c|c|}
\hline Foundation Name & $\begin{array}{c}\text { Dollar } \\
\text { Amount }\end{array}$ & $\begin{array}{l}\text { No. of } \\
\text { Grants }\end{array}$ \\
\hline $\begin{array}{l}\text { 1. Robert W. Woodruff Foundation, } \\
\text { Inc. }\end{array}$ & $\$ 8,045,016$ & 12 \\
\hline $\begin{array}{l}\text { 2. The Carlos and Marguerite Mason } \\
\text { Fund }\end{array}$ & $4,764,092$ & 13 \\
\hline $\begin{array}{l}\text { 3. The Community Foundation for } \\
\text { Greater Atlanta, Inc. }\end{array}$ & $4,344,529$ & 68 \\
\hline $\begin{array}{l}\text { 4. Healthcare Georgia Foundation, } \\
\text { Inc. }\end{array}$ & $3,319,500$ & 31 \\
\hline 5. The Marcus Foundation, Inc. & $3,570,172$ & 15 \\
\hline 6. J. Bulow Campbell Foundation & $2,900,000$ & 4 \\
\hline 7. The Aflac Foundation, Inc. & $2,823,122$ & 9 \\
\hline 8. Callaway Foundation, Inc. & $2,100,000$ & 3 \\
\hline $\begin{array}{l}\text { 9. The Arthur M. Blank Family } \\
\text { Foundation }\end{array}$ & $2,212,000$ & 9 \\
\hline $\begin{array}{l}\text { 10. The M. L. Simpson Foundation } \\
\text { Trust }\end{array}$ & $2,000,000$ & 1 \\
\hline
\end{tabular}

Source: The Foundation Center

*Detail about these foundations is in the mini-directory.

Top 10 non-Georgia foundations giving health dollars to Georgia recipients in 2005

\begin{tabular}{lrr}
\hline \multicolumn{1}{c}{ Foundation Name } & $\begin{array}{r}\text { Dollar } \\
\text { Amount }\end{array}$ & $\begin{array}{r}\text { No. of } \\
\text { Grants }\end{array}$ \\
\hline 1. Bill \& Melinda Gates Foundation & $\$ 26,572,554$ & 3 \\
2. The Robert Wood Johnson & $4,481,772$ & 21 \\
Foundation & $4,153,194$ & 2 \\
3. W. K. Kellogg Foundation & $2,100,000$ & 1 \\
4. W. M. Keck Foundation & $1,366,500$ & 1 \\
5. Conrad N. Hilton Foundation & $1,171,000$ & 3 \\
6. The Ford Foundation & $1,150,000$ & 2 \\
7. The Samuel Roberts Noble & $1,000,000$ & 2 \\
Foundation, Inc. & 840,326 & 8 \\
8. Burroughs Wellcome Fund & 750,000 & 1 \\
9. The Pfizer Foundation, Inc. & & \\
10. The Picower Foundation & &
\end{tabular}

Source: The Foundation Center

Top 10 recipients of health grants in Georgia in 2005

\begin{tabular}{|c|c|c|c|}
\hline & & $\begin{array}{l}\text { Health Grant } \\
\text { Dollars }\end{array}$ & No. of \\
\hline Foundation Name & City & Received & Grants \\
\hline 1. Carter Center & Atlanta & $\$ 26,572,554$ & 8 \\
\hline 2. Emory University & Atlanta & $10,574,729$ & 24 \\
\hline $\begin{array}{l}\text { 3. Children's Healthcare of } \\
\text { Atlanta }\end{array}$ & Atlanta & $7,473,213$ & 13 \\
\hline 4. Morehouse College & Atlanta & $4,000,000$ & 1 \\
\hline 5. CDC Foundation & Atlanta & $3,327,794$ & 10 \\
\hline 6. Shepherd Center & Atlanta & $2,533,497$ & 8 \\
\hline 7. Atlanta Speech School & Atlanta & $2,325,236$ & 3 \\
\hline $\begin{array}{l}\text { 8. Medical College of } \\
\text { Georgia Foundation }\end{array}$ & Augusta & $2,172,324$ & 3 \\
\hline $\begin{array}{l}\text { 9. Children's Healthcare of } \\
\text { Atlanta Foundation }\end{array}$ & Atlanta & $2,074,475$ & 8 \\
\hline $\begin{array}{l}\text { 10. George West Mental } \\
\text { Health Foundation }\end{array}$ & Atlanta & $2,060,000$ & 3 \\
\hline
\end{tabular}




\section{GEORGIA'S HEALTH RANKINGS}

Below are selected indicators of the health and wellbeing of Georgians relative to residents of the other 49 states. The rankings fall within the range of 1-50, with a ranking of 1 being most desirable and a ranking of 50 being least desirable. For more information about these rankings, please contact Healthcare Georgia Foundation at (404) 653-0990.

\begin{tabular}{|c|c|c|c|c|}
\hline CATEGORY & INDICATOR & $\begin{array}{l}\text { VALUE OF } \\
\text { INDICATOR (GA) }\end{array}$ & $\begin{array}{l}\text { VALUE OF } \\
\text { INDICATOR (US) }\end{array}$ & $\begin{array}{l}\text { GEORGIA'S } \\
\text { RANK }\end{array}$ \\
\hline \multicolumn{5}{|c|}{ HEALTH RISKS } \\
\hline & $\%$ of adults who Smoke & $22.1 \%$ & $20.6 \%$ & 34 \\
\hline & $\begin{array}{l}\text { Total number of teens ( } 12-17 \text { yrs) needing but not receiving } \\
\text { treatment for lllicit Drug Use in past year }\end{array}$ & 34,000 & $1,238,000$ & 41 \\
\hline \multicolumn{5}{|l|}{ HEALTH CARE } \\
\hline & $\%$ of population without Insurance & $18.9 \%$ & $15.9 \%$ & 45 \\
\hline & Per capita expenditures on Mental Health & $\$ 49.9$ & $\$ 84.7$ & 43 \\
\hline & Hospital ER visits per 1,000 population & 392 & 383 & 26 \\
\hline & Registered Nurses per 100,000 population & 658 & 799 & 43 \\
\hline & $\%$ of population without access to Primary Care & $15.6 \%$ & $11.5 \%$ & 39 \\
\hline \multicolumn{5}{|c|}{ HEALTH OUTCOMES } \\
\hline & $\%$ of Low Birthweight babies & $9.3 \%$ & $8.1 \%$ & 44 \\
\hline & Teenage Birth Rate (live births per 1,000 females $15-19$ yrs old) & 54.5 & 42.0 & 43 \\
\hline & Infant Mortality rate (infant deaths per 1,000 live births) & 8.4 & 6.6 & 41 \\
\hline \multicolumn{5}{|c|}{ SOCIOECONOMIC INDICATORS } \\
\hline & $\%$ of children in Poverty & $21.2 \%$ & $17.6 \%$ & 42 \\
\hline & Teens who are High School Dropouts & $10.0 \%$ & $7.0 \%$ & 47 \\
\hline
\end{tabular}

Healthcare Georgia Foundation

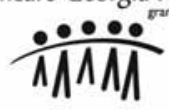

ABOUT HEALTHCARE GEORGIA FOUNDATION

Healthcare Georgia Foundation is a statewide, private independent foundation whose mission is to advance the health of all Georgians and to expand access to affordable, quality healthcare for underserved individuals and communities.

healthcaregeorgia.org

\section{FOUNDATION CENTER}

Knowledge to build on.

50 Hurt Plaza, Suite 150 Atlanta, GA 30303

(404) 880-0094 foundationcenter.org/atlanta

\section{For More Information}

Download "Spotlight on Health Grantmaking" in Georgia at foundationcenter.org/atlanta.

Learn more about health grantmaking at the Foundation Center-Atlanta or a Cooperating Collection near you at foundationcenter.org/collections.

For more information, contact Pattie Johnson, director of the Foundation Center-Atlanta, at (404) 880-0095 or pjj@foundationcenter.org. 